\title{
IDŐJÁRÁS
}

Quarterly Journal of the Hungarian Meteorological Service

Vol. 123, No. 2, April-June, 2019, pp. 203-215

\section{Online coupled modeling of weather and air quality of Budapest using the WRF-Chem model}

\author{
Attila Kovács ${ }^{1}$, Ádám Leelőssy ${ }^{1}$, Róbert Mészáros $^{1, *}$, and István Lagzi ${ }^{2,3}$ \\ ${ }^{1}$ Eötvös Loránd University, Department of Meteorology \\ Pázmány Péter sétány 1/A, 1117 Budapest, Hungary \\ ${ }^{2}$ Budapest University of Technology and Economics \\ Department of Physics \\ Budafoki út 8, 1111 Budapest, Hungary \\ ${ }^{3}$ MTA-BME Condensed Matter Research Group \\ Budafoki út 8, 1111 Budapest, Hungary \\ *Corresponding authorE-mail:mrobi@nimbus.elte.hu
}

(Manuscript received in final form October 18, 2018)

\begin{abstract}
WRF-Chem is a numerical Eulerian non-hydrostatic mesoscale weather prediction model online coupled with the atmospheric chemistry model, developed mainly by the National Center for Atmospheric Research (NCAR) and the National Oceanic and Atmospheric Administration (NOAA). This model system is a frequently used tool for creating high resolution air quality simulations at different spatial and temporal scales for various air pollutants. In this study, the technical backgrounds of the WRF-Chem model applied for high resolution urban air quality forecasts in Budapest are presented. The meteorological module of the system uses the WRF-ARW (Weather Research and Forecasting - Advanced Research WRF) dynamical solver, and obtains its initial and boundary conditions from the GFS (Global Forecast System) using a horizontal resolution of $0.25 \times 0.25$ degree. By applying two nested model domains (with $15 \times 5 \mathrm{~km}$ horizontal resolution), fine resolution meteorological fields can be achieved. In the chemical module, the National Emission Inventories created by the Hungarian Meteorological Service were applied, different chemical reaction sets were used and tested, and constant deposition rates were assumed. In this work, a case study for different pollutants $\left(\mathrm{O}_{3}, \mathrm{NO}, \mathrm{NO}_{2}\right.$, and $\left.\mathrm{CO}\right)$ is presented for an early summer period of 2015 .
\end{abstract}

Key-words: WRF-Chem, air pollution, photochemical mechanism, tropospheric ozone 


\section{Introduction}

Outdoor air pollution is a serious environmental issue in Hungary, especially in winters. Ambient air quality thresholds for $\mathrm{NO}_{2}$ and $\mathrm{PM}_{10}$ are regularly exceeded (Mészáros et al., 2013). The Aphekom project found that in the period of 20082011, the life expectancy was decreased by 19 months in Budapest due to the outdoor air pollution (Pascal et al., 2013). The World Health Organization (WHO) found that in 2012, approximately 8,000 premature deaths could be attributed to polluted ambient air in Hungary $(W H O, 2016)$. The main sources of $\mathrm{PM}_{10}$ and ozone air pollution are domestic heating, road traffic, and large-scale transport of air pollutants (Ferenczi, 2013; Kis-Kovács et al., 2017). The European Union expects effective strategies to diminish the effect of air pollution, however, policymaking requires the good understanding of the fine scale urban environmental processes and the reliable prediction of air quality for the following days. Operational air quality prediction is performed by the Hungarian Meteorological Service using the CHIMERE air dispersion model offline coupled with the WRF numerical weather prediction model (Ferenczi et al., 2014).

Online coupled weather and air quality modeling have become a powerful and widely applied tool to predict and evaluate air pollution on the regional scale (Baklanov et al., 2014). In Europe, numerical air quality forecasts are available from several continental scale atmospheric chemistry transport models, mainly those of the Copernicus Atmospheric Monitoring Service (CAMS) cooperation (https://atmosphere.copernicus.eu/). Its models use a grid of 0.1 degree resolution on the continental scale to operationally predict atmospheric concentrations of the main air pollutants, as well as pollens and volcanic ash (Marécal et al., 2015). However, for cities and other sensitive areas, a finer model resolution might be necessary, especially if the emission inventory is available on a fine scale. This can be achieved by a nested atmospheric chemistry transport model that can reach very fine $(1-3 \mathrm{~km})$ resolution for a limited area (Kuik et al., 2016; Liu et al., 2018).

WRF-Chem is an atmospheric chemistry and transport module online integrated with the extremely popular Weather Research and Forecast (WRF) numerical weather prediction model. It solves the governing equations of atmospheric dynamics, tracer transport, and chemical reactions within one model system, sharing the same grid and timesteps (Grell et al., 2005). Online coupling enables the model to simulate the feedbacks of air pollution on the weather, especially the effects of atmospheric aerosols (Kong et al., 2015). On the other hand, online coupling of the meteorology and transport simulation can gain better accuracy in complex weather situations by accessing the full planetary boundary layer (PBL) parameterization of the weather forecast model and avoiding the information bottleneck of derived output parameters (Baklanov et al., 2014; Leelössy et al., 2017). 
WRF-Chem has been used in several countries for regional and urban scale air pollution forecast. In recent years, nested WRF-Chem simulations focusing on urban air pollution have been presented for cities such as Berlin (Kuik et al., 2016), Madrid (José et al., 2015), Los Angeles (Kim S.-W. et al., 2016), for several metropolitan regions in China (Liao et al., 2015; Zhang et al., 2015; Liu et al., 2018), and even for the complex terrain of Kathmandu (Mues et al., 2017). However, comparison studies proved that WRF-Chem model results show a large sensitivity on the selection of the chemistry scheme, both regarding the tropospheric ozone (Mar et al., 2016) and secondary aerosol (Balzarini et al., 2015) formation. For example, in a photochemical box model, 25\% difference was found between $\mathrm{NO}_{\mathrm{x}}$ concentrations obtained with different chemical mechanisms (Knote et al., 2015).

In this paper, we investigate the applicability of WRF-Chem (numerical weather prediction and atmospheric chemistry and transport) model to simulate and estimate concentration levels and diurnal variation of ozone and nitrogen oxides in Budapest and other sites in Hungary.

\section{Methods}

The WRF-Chem coupled meteorology-chemistry model was applied for air pollutant transport simulation using two nested domains (Fig. 1). The external domain covered Central Europe ranging 1,500 $\times 1,050 \mathrm{~km}$ with horizontal resolution of $15 \mathrm{~km}$. The internal, 5-km-resolution domain had a size of $560 \times 350 \mathrm{~km}$, covering Hungary entirely. The number of horizontal grid points was therefore 7,000 and 7,840 in the external and internal domain, respectively. The same 40 vertical levels between 1,000 and $50 \mathrm{hPa}$ were applied in both domains. Lateral boundary conditions were provided by the GFS (Global Forecast System) global model with a horizontal and temporal resolution of $0.25^{\circ}$ and 3 hours, respectively. Lower boundary conditions are obtained from static geographical input data by the WRF Preprocessing System (WPS). The applied parameterization schemes are presented in Table 1.

Pollutant emissions were obtained from the 2015 National Emission Ceiling Directive - Informative Inventory Report of the Hungarian Meteorological Service (Kis-Kovács et al., 2017). NECD-IIR provided estimates of the total annual release of 15 air pollutants on a horizontal grid covering Hungary with a resolution of $0.1^{\circ} \times 0.1^{\circ}$. In this study, the emission inventories of $\mathrm{NO}_{\mathrm{x}}$, NMVOCs (non-methane volatile organic compounds) and $\mathrm{CO}$ were used. NMVOC emission was added to the model input as isoprene emission. 
Table 1. The configuration of the WRF-Chem model runs

\begin{tabular}{ll}
\hline \hline Physical/chemical process & \multicolumn{1}{c}{ Applied scheme } \\
\hline \hline Planetary boundary layer & Mellor-Yamada-Janjic scheme \\
Microphysics & WRF Single-Moment 6-class scheme \\
Photolysis & Fast-J photolysis \\
Gas-phase chemistry & Regional Acid Deposition Model 2 \\
Longwave radiation & Rapid Radiative Transfer Model \\
Shortwave radiation & Old Goddard scheme \\
Cumulus convection & Grell-Freitas ensemble scheme \\
Urban canopy & Building Environment Parameterization \\
Land surface process & Noah Land Surface Model \\
Surface layer scheme & Monin-Obukhov Janjic Eta similarity scheme \\
\hline
\end{tabular}

The annual emission value was uniformly distributed in the year, therefore, the temporal variability of the emissions could not be considered in this model. However, due to the fine spatial resolution of both the emission inventory and the computational domain, the differences in urban and rural air pollution could be well investigated.

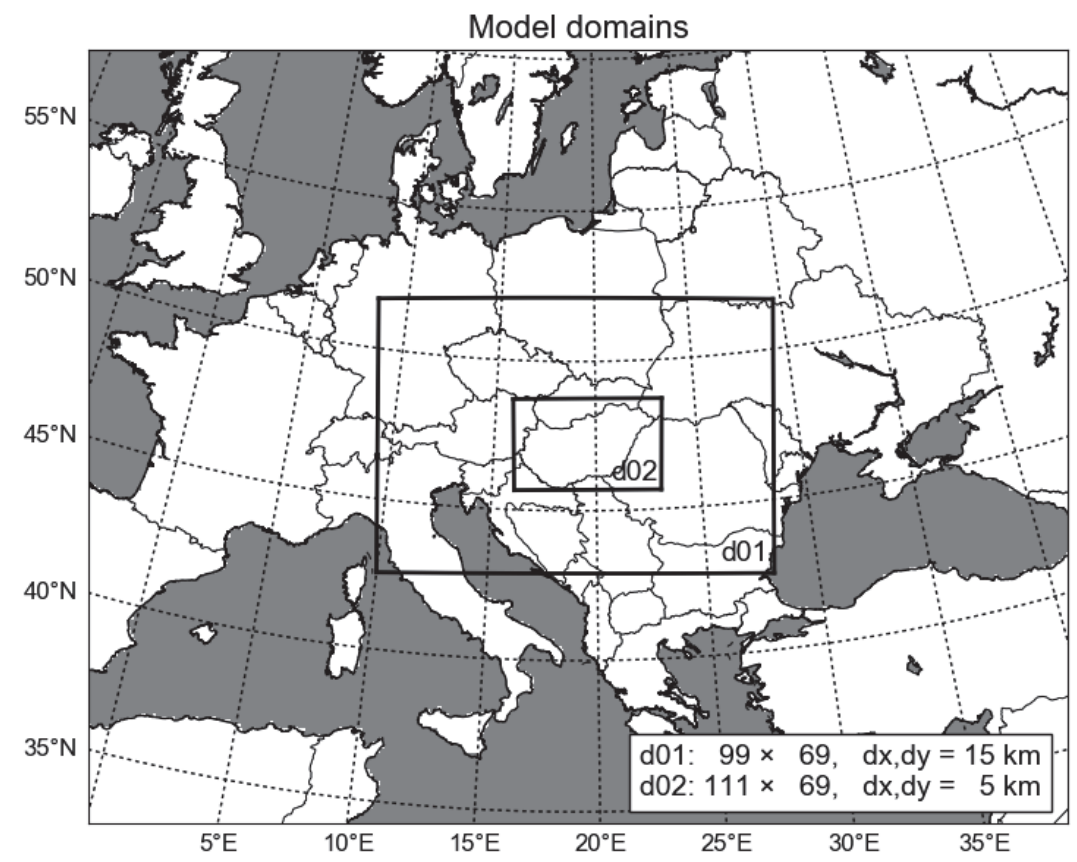

Fig. 1. The two nested computational domains of the WRF-Chem simulations. 
A period of four days was simulated with the WRF-Chem model. The first day (May 15, 2015) was a spin-up period for the meteorological component, and only the meteorological calculations were performed by the model. The second day (May 16, 2015) was used as a spin-up phase for the chemistry model and was then discarded. The third and fourth days (May 17 and 18, 2015) were considered as the model results.

A summer period with calm anticyclonic weather was selected for the investigation of the photochemical ozone production from 2015, the reference year of the IIR emission inventory. The spin-up day for meteorology has been used to create the atmospheric initial conditions for the WRF domains corresponding to the GFS boundary conditions, as no data assimilation was performed. Initial and lateral boundary conditions for chemistry have been set to zero, and the chemistry spin-up period was used to create the initial concentration field corresponding to the emission inventory. By choosing a period with calm weather and weak winds, the effect of local emissions could be investigated.

Model results were compared to measurement data from the following automatic monitoring stations of the Hungarian Air Quality Network: Budapest (Gilice tér station in the south-eastern suburbs of the city), Pécs, Györ, Debrecen, and K-Puszta (field monitoring station) (Fig. 2).

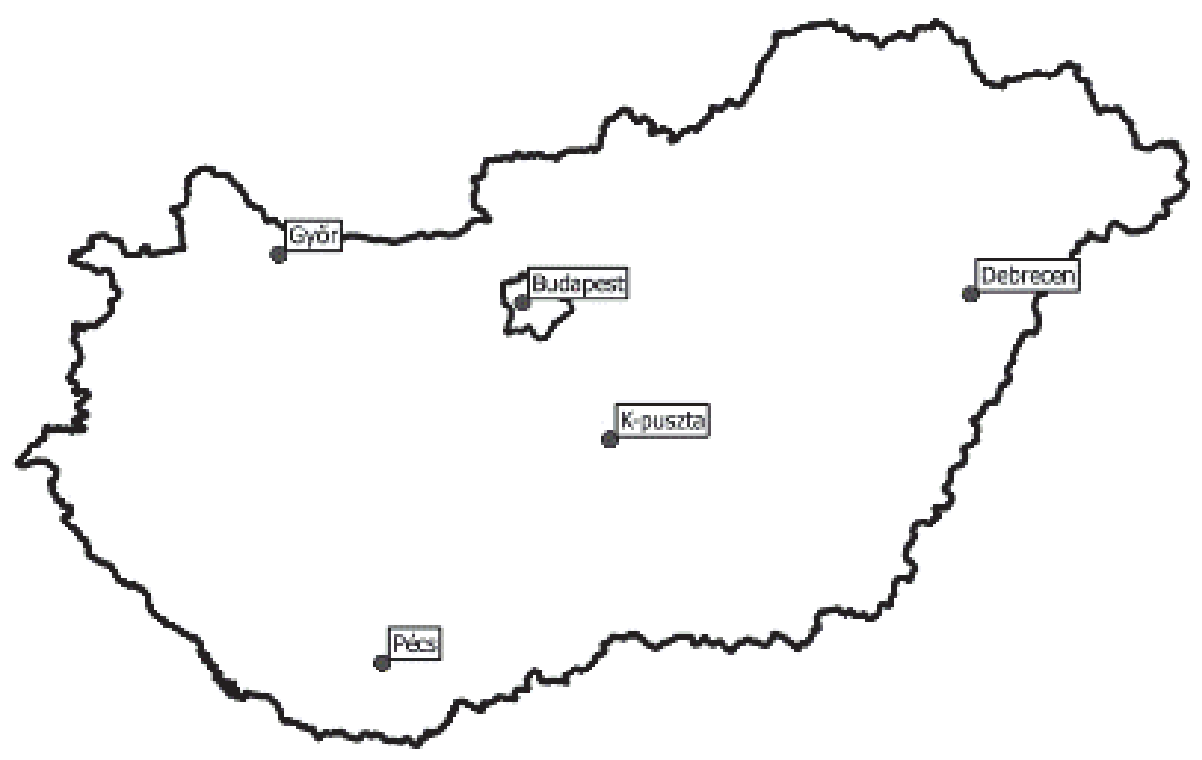

Fig. 2. Air quality monitoring sites of the Hungarian Air Quality Network where the model comparison was performed. 
Two chemical mechanisms have been compared: the RADM2 (Regional Acid Deposition Model 2nd generation) and the CBMZ (Carbon-Bond Mechanism version Z), both with and without a KPP (Kinetic PreProcessor) solver (Stockwell et al., 1990; Zaveri and Peters, 1999). RADM2 mechanism contains 21 and 42 inorganic and organic chemical species, respectively, with 158 chemical reactions out of them 21 are photochemical reactions (Gross and Stockwell, 2003). CBMZ is a modified and updated version of the CBM-IV mechanism (Gery et al., 1989), which contains 52 chemical species with 132 chemical reactions (Zaveri and Peters, 1999).

\section{Results}

Despite the stationary emission rates of $\mathrm{CO}, \mathrm{NO}$, and $\mathrm{NO}_{2}$, the simulated $\mathrm{O}_{3}$ concentration data were consistent with the typical diurnal cycle of ozone and the measurement data provided by the monitoring stations (Fig. 3). The highest concentrations of ozone were observed in the afternoon, especially between 15-18 UTC, reaching $100 \mu \mathrm{g} / \mathrm{m}^{3}$. (The solar time in Budapest was UTC + 80 minutes on these days.) The diurnal cycle was well captured by all chemical mechanisms. A general underestimation can be observed in the results obtained with the CBMZ mechanism, while RADM2 was found to provide generally higher ozone concentrations. This is surprising in the context of a year-long European-scale study, where RADM2 showed a significant negative bias (Mar et al., 2016). Ozone rapidly decayed in the model during the night in both CBMZ and the RADM2-KPP runs. However, the RADM2 mechanism without KPP resulted in a relatively high $\left(20-50 \mu \mathrm{g} / \mathrm{m}^{3}\right)$ residual night-time ozone concentration near the surface. Apart from this effect, there was generally a very small difference between results obtained with and without the kinetic preprocessor.

The modeled diurnal cycle of the NO concentration was close to the observed one, but lacked the night peak from 18 UTC to 00 UTC. The RADM2 and RADM2-KPP mechanisms overestimated the peak $\mathrm{NO}_{2}$ levels by a factor of 2, unlike the CBMZ and CBMZ-KPP mechanisms, which gave a much better correspondence with the observed concentrations. The simulations provided almost the same $\mathrm{CO}$ concentration levels with all chemical settings. The temporal evolution of $\mathrm{CO}$ concentrations was well reproduced, however, the models yielded significantly lower values than the measurement data. It must be noted that due to the high uncertainty of the emission inventory and the limited representativity of urban monitoring sites, the model errors can hardly be attributed quantitatively to the applied chemical mechanisms. 

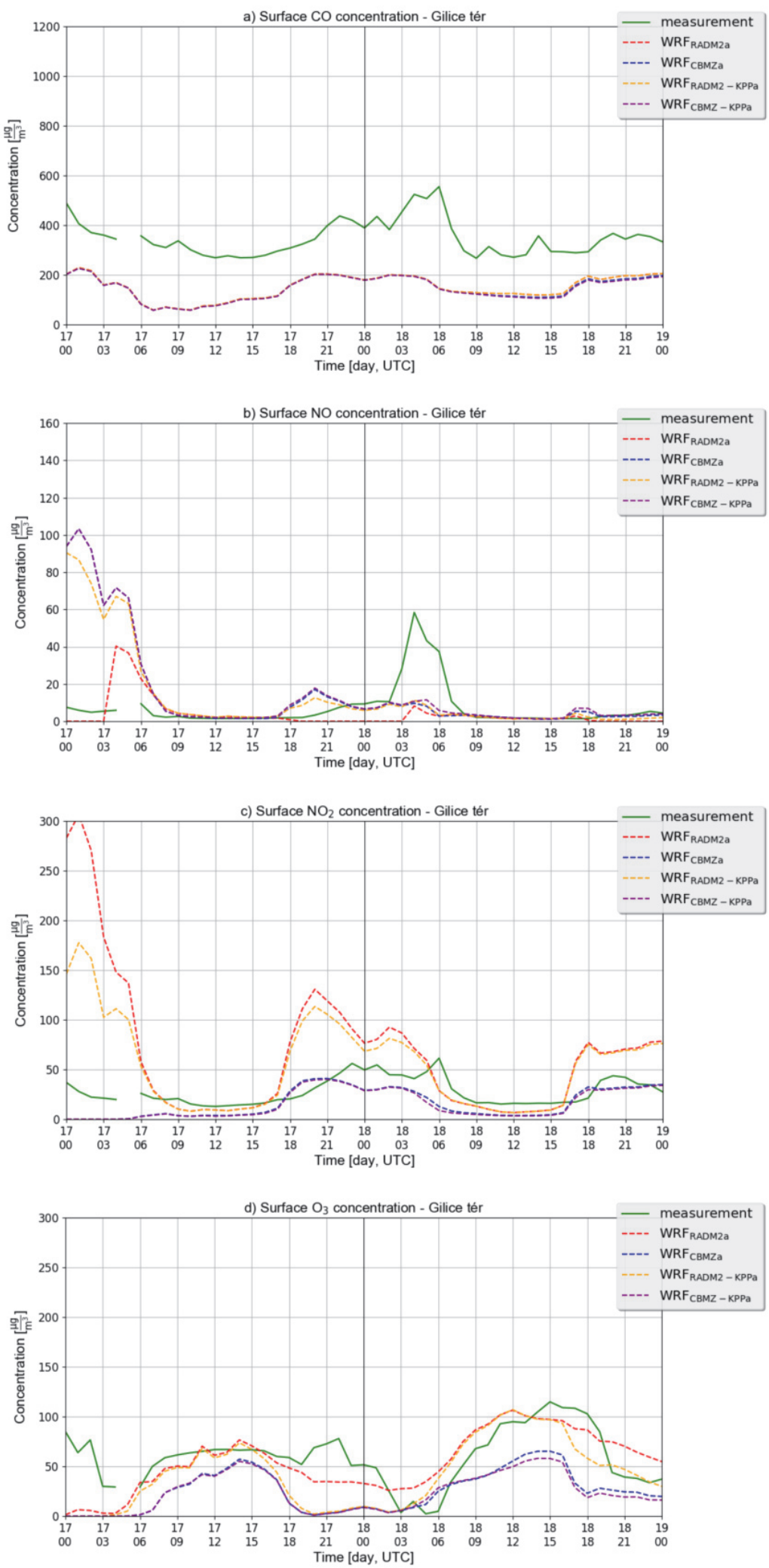

Fig. 3. Measured and modeled concentration of air pollutants on May 17-18, 2015 in Budapest, Gilice tér. Dashed lines: time series of simulated near-surface concentrations of a) $\mathrm{CO}, \mathrm{b}) \mathrm{NO}, \mathrm{c}) \mathrm{NO}_{2}$, and d) $\mathrm{O}_{3}$, respectively. Green line: time series of hourly measured concentrations. (Source of measured data: Hungarian Air Quality Network http://www.levegominoseg.hu/). 
As the NECD-IIR database provided the total $\mathrm{NO}_{\mathrm{x}}$ emission data for nitrogen oxides, the sensitivity of the chemical mechanism was investigated for the initial $\mathrm{NO} / \mathrm{NO}_{\mathrm{x}}$ ratio. For the first set of simulations (a) the $\mathrm{NO} / \mathrm{NO}_{\mathrm{x}}$ proportion in the initial $\mathrm{NO}_{\mathrm{x}}$ emission data was set to the simplistic 0.50 ratio, to 0.75 for the second sequence (b), and to 0.25 for the final series (c).

Fig. 4 shows the simulated $\mathrm{O}_{3}$ concentrations using the RADM2-KPP and CBMZ-KPP chemical mechanisms, each with applying the three $\mathrm{NO}-\mathrm{NO}_{2}$ scenarios. Only two of four mechanisms are shown, because there was no considerable difference between the CBMZ and the CBMZ-KPP mechanism in the $\mathrm{O}_{3}$ concentrations, and the alteration of the $\mathrm{NO}-\mathrm{NO}_{2}$ distribution in the $\mathrm{NO}_{\mathrm{X}}$ emission did not affect the model output concentrations in the case of the RADM2 chemical mechanism. The sensitivity of $\mathrm{O}_{3}$ concentration on the initial $\mathrm{NO} / \mathrm{NO}_{\mathrm{x}}$ ratio was very low during the day, however, the decreased direct $\mathrm{NO}$ emission in the (c) scenario caused higher night-time ozone levels due to the weakening of the $\mathrm{NO}-\mathrm{O}_{3}$ reaction.
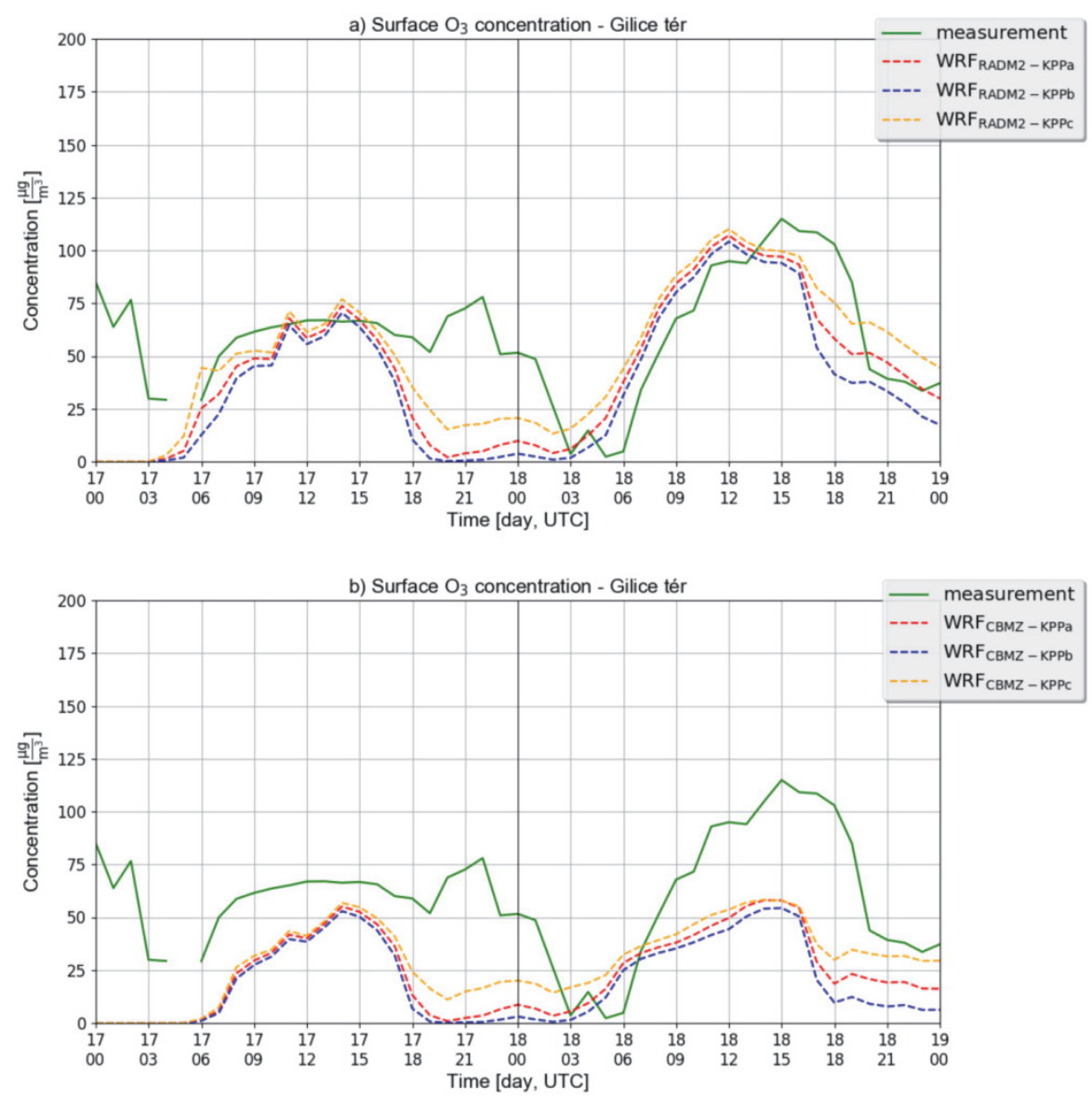

Fig. 4. Measured and modeled concentration of air pollutants on May 17-18, 2015 in Budapest, Gilice tér using the RADM2 (a) and CBMZ (b) chemical model. Dashed lines: time series of simulated near-surface concentrations of $\mathrm{O}_{3}$ using different $\mathrm{NO} / \mathrm{NO}_{2}$ emission ratios, $\mathrm{NO} / \mathrm{NO}_{\mathrm{x}}=0.5$ (red dashed line), $\mathrm{NO} / \mathrm{NO}_{\mathrm{x}}=0.75$ (blue dashed line), and $\mathrm{NO} / \mathrm{NO}_{\mathrm{x}}=$ 0.25 (yellow dashed line). Solid green line: time series of measured concentrations. (Source of measurement data: Hungarian Air Quality Network - http://www.levegominoseg.hu/). 
Fig. 5 shows the simulated concentration field of $\mathrm{O}_{3}$ at 12 UTC, May 18, 2015 using the RADM2-KPP chemical mechanism. The $10 \mathrm{~m}$ wind field is also presented by wind barbs. A large plume indicates Budapest, the capital and biggest city of Hungary in the north central part of the country. This plume of ozone was formed by the significant urban emissions of $\mathrm{NO}_{\mathrm{x}}$ and was transported north-westward by light near-surface winds. (Fig. 5).

A comparison of measured and modeled ozone concentrations at selected monitoring sites are presented in Fig. 6. Pécs, Győr, and Debrecen are urban sites, while K-Puszta is a background site located in an agricultural area. The diurnal cycle of ozone was generally well captured by the model, and the RADM2 mechanism yielded higher - more realistic - ozone concentrations, while results obtained with the CBMZ scheme showed a serious underestimation. The best agreement of model results with observations was found at the background station K-Puszta that had the largest spatial representativity (Fig. 6). At the urban sites of Györ, Pécs, and Debrecen, a secondary night-time ozone peak was observed, which could not be captured by the model.

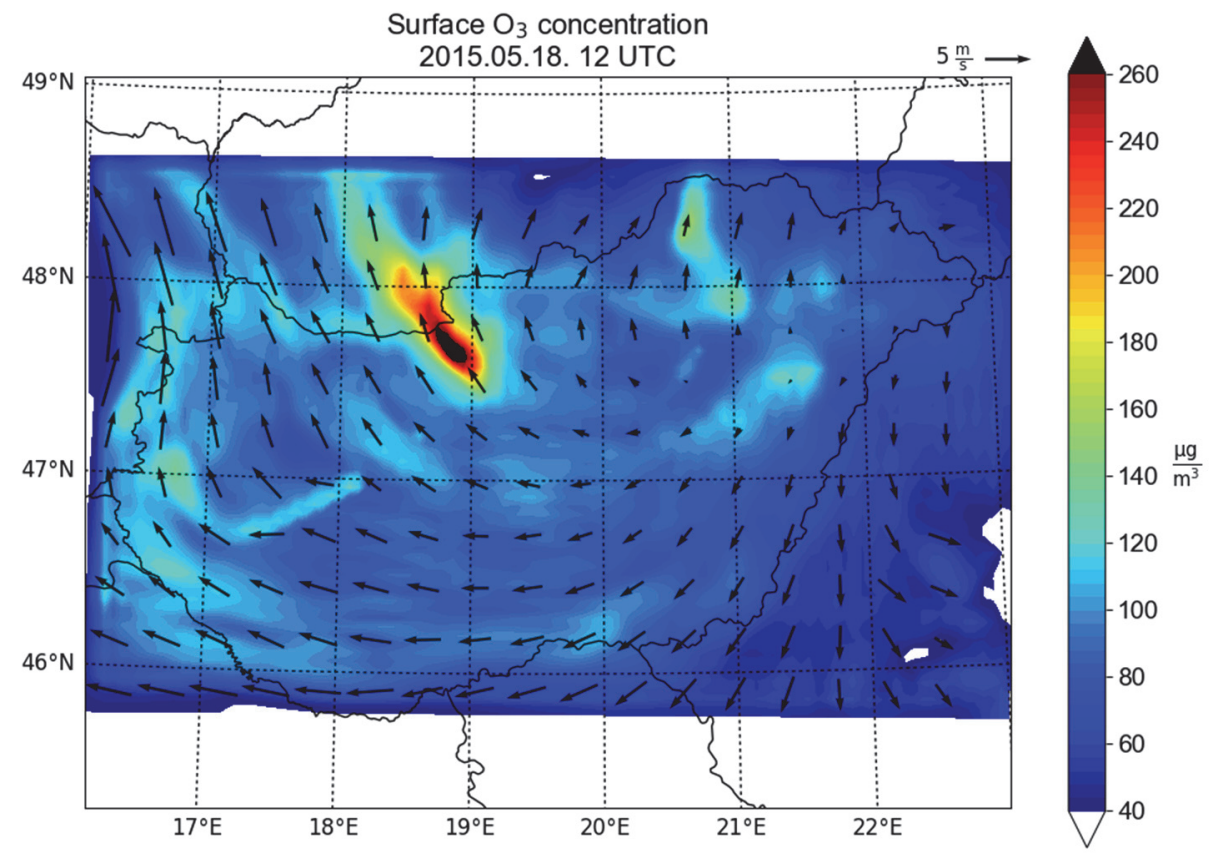

Fig. 5. Simulated near-surface ozone concentration and $10 \mathrm{~m}$ wind field at $12 \mathrm{UTC}$, May 18 , 2015, using WRF-Chem with the RADM2-KPP chemical mechanism. 

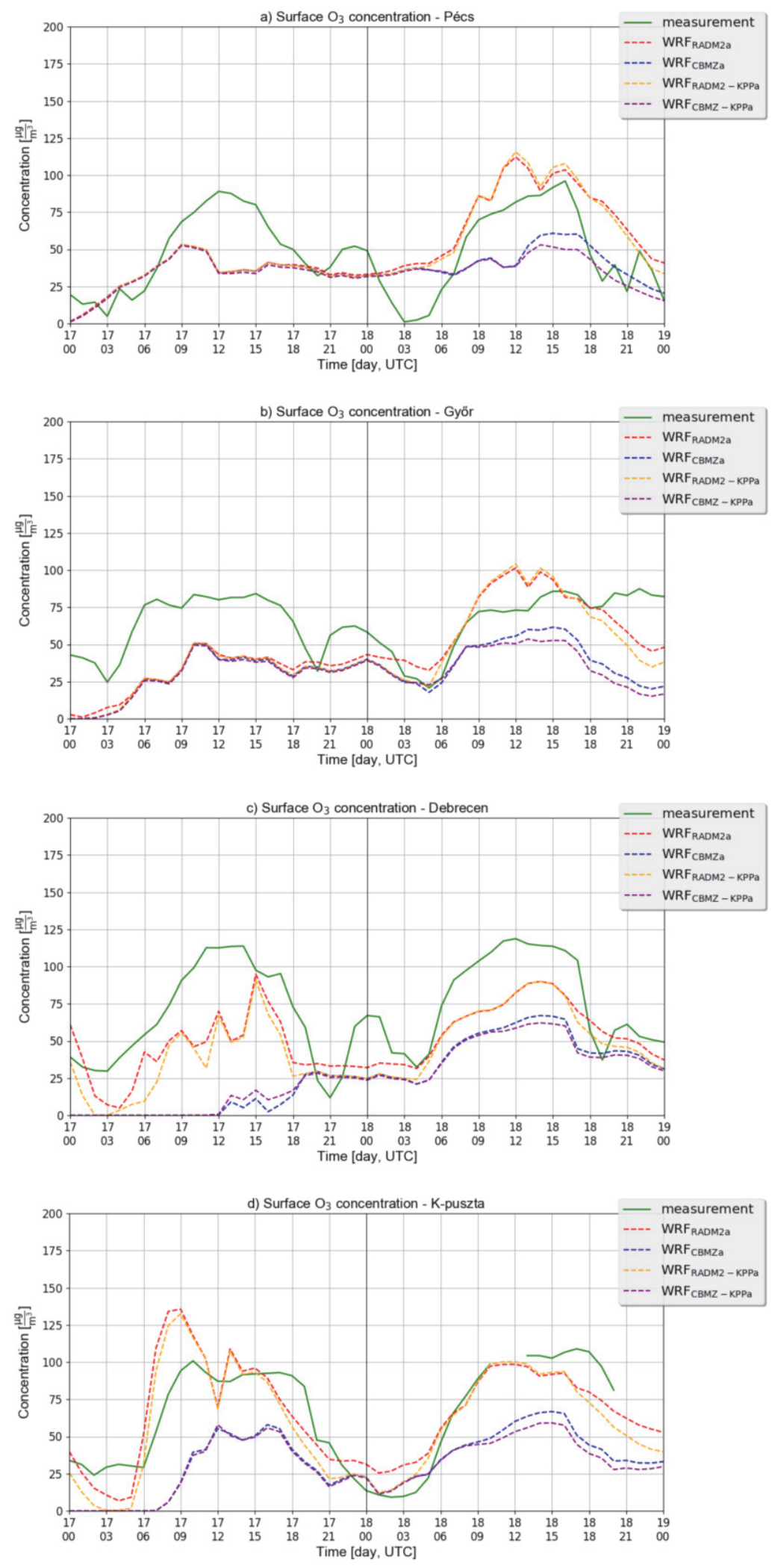

Fig. 6. Measured and modeled concentration of air pollutants on May 17-18, 2015 in a) Pécs, b) Győr, c) Debrecen, and d) K-puszta. Dashed lines: time series of simulated near-surface concentrations of $\mathrm{O}_{3}$ on May 17-18, 2015 at 4 locations within Hungary using different chemical mechanisms. Green line: time series of measured $\mathrm{O}_{3}$ concentration at the respective monitoring sites. (Source of measurement data: Hungarian Air Quality Network http://www.levegominoseg.hu/). 


\section{Conclusion}

An online coupled atmospheric chemistry transport modeling application has been presented to simulate the air pollution of Hungary. Simulations were performed with the WRF-Chem model using two nested domains covering Central Europe and Hungary. With this method, a relatively low horizontal resolution $(5 \mathrm{~km})$ could be achieved at an acceptable computational cost. Provided with meteorological boundary conditions from the Global Forecast System (GFS) and emission data from the NERC-IIR national emission inventory, the model could simulate the atmospheric dispersion of pollutants and the photochemical ozone formation.

Model capabilities were demonstrated through a case study for May 17-18, 2015, comparing two chemical mechanisms (RADM2 and CBMZ), both with and without the kinetic pre-processor (KPP). Emission inventories of $\mathrm{NO}_{\mathrm{x}}$, nonmethane VOCs, and $\mathrm{CO}$ were considered. Model results were compared to measurements taken at monitoring sites of the Hungarian Air Quality Network (OLM). The diurnal cycle of ozone was generally well captured by the model despite the stationary emission field. However, a large difference was found between the two applied chemical mechanisms. RADM2 provided generally higher and more realistic ozone concentrations, however, it seriously overestimated $\mathrm{NO}_{2}$ levels. Results showed low sensitivity on the application of the kinetic pre-processor and the initial $\mathrm{NO} / \mathrm{NO}_{2}$ ratio.

Acknowledgement: This work was supported by the National Research, Development and Innovation Office of Hungary (No. K116506, K128805-K128818).

\section{References}

Baklanov, A., Schlünzen, K., Suppan, P., Baldasano, J., Brunner, D., Aksoyoglu, S., Carmichael, G., Douros, J., Flemming, J., Forkel, R., Galmarini, S., Gauss, M., Grell, G., Hirtl, M., Joffre, S., Jorba, O., Kaas, E., Kaasik, M., Kallos, G., Kong, X., Korsholm, U., Kurganskiy, A., Kushta, J., Lohmann, U., Mahura, A., Manders-Groot, A., Maurizi, A., Moussiopoulos, N., Rao, S.T., Savage, N., Seigneur, C., Sokhi, R.S., Solazzo, E., Solomos, S., Sørensen, B., Tsegas, G., Vignati, E., Vogel, B., and Zhang, Y., 2014: Online coupled regional meteorology chemistry models in Europe: current status and prospects. Atmos. Chem. Physics 14, 317-398. https://doi.org/10.5194/acp-14-317-2014

Balzarini, A., Pirovano, G., Honzak, L., Žabkar, R., Curci, G., Forkel, R., Hirtl, M., San José, R., Tuccella, P., and Grell, G.A., 2015: WRF-Chem model sensitivity to chemical mechanisms choice in reconstructing aerosol optical properties. Atmos. Environ. 115, 604-619. https://doi.org/10.1016/j.atmosenv.2014.12.033

Ferenczi, Z., 2013: Predictability analysis of the $\mathrm{PM}_{2.5}$ and $\mathrm{PM}_{10}$ concentration in Budapest. Idöjárás $117,359-375$.

Ferenczi, Z., Labancz, K., and Steib, R., 2014: Development of a Numerical Prediction Model System for the Assessment of the Air Quality in Budapest, In (eds. Steyn, D. and Mathur, R.) Air Pollution Modeling and Its Application. XXIII, Springer Proceedings in Complexity, Springer International Publishing, 401-405. 
Gery, M.W., Whitten, G.Z., Killus, J.P., and Dodge, M.C., 1989: A photochemical kinetics mechanism for urban and regional scale computer modeling. J. Geophys. Res. Atmospheres 94, 12925 12956. https://doi.org/10.1029/JD094iD10p12925

Grell, G.A., Peckham, S.E., Schmitz, R., McKeen, S.A., Frost, G., Skamarock, W.C., and Eder, B., 2005: Fully coupled "online" chemistry within the WRF model. Atmos. Environ. 39, 69576975. https://doi.org/10.1016/j.atmosenv.2005.04.027

Gross, A., and Stockwell, W.R., 2003: Comparison of the EMEP, RADM2 and RACM Mechanisms. J. Atmos. Chem. 44, 151-170. https://doi.org/10.1023/A:1022483412112

José, R.S., Pérez, J.L., Pecci, J., Garzón, A., and Palacios, M., 2015: Comparison between different dynamical downscaling methods using WRF-Chem for urban applications: Madrid case study. Int. J. Environ. Pollut. 58, 293-306. https://doi.org/10.1504/IJEP.2015.077459

Kim S.-W., McDonald B. C., Baidar S., Brown S. S., Dube B., Ferrare R. A., Frost G. J., Harley R. A., Holloway J. S., Lee H.J., McKeen S. A., Neuman J. A., Nowak J. B., Oetjen H., Ortega I., Pollack I. B., Roberts J. M., Ryerson T. B., Scarino A. J., Senff C. J., Thalman R., Trainer M., Volkamer R., Wagner N., Washenfelder R. A., Waxman E., and Young C. J., 2016: Modeling the weekly cycle of NOx and $\mathrm{CO}$ emissions and their impacts on O3 in the Los Angeles-South Coast Air Basin during the CalNex 2010 field campaign. J. Geophys. Res. Atmospheres 121, 1340-1360. https://doi.org/10.1002/2015JD024292

Kis-Kovács, G., Tarczay, K., Köbányai, K., Ludányi, E., Nagy, E., and Lovas, K., 2017: Informative Inventory Report 1990-2015. Hungarian Meteorological Service, Unit of National Emissions Inventories, Budapest.

Knote, C., Tuccella, P., Curci, G., Emmons, L., Orlando, J.J., Madronich, S., Baró, R., JiménezGuerrero, P., Luecken, D., Hogrefe, C., Forkel, R., Werhahn, J., Hirtl, M., Pérez, J.L., San José, R., Giordano, L., Brunner, D., Yahya, K., and Zhang, Y., 2015: Influence of the choice of gasphase mechanism on predictions of key gaseous pollutants during the AQMEII phase-2 intercomparison. Atmos. Environ. 115, 553-568.

https://doi.org/10.1016/j.atmosenv.2014.11.066

Kong, X., Forkel, R., Sokhi, R.S., Suppan, P., Baklanov, A., Gauss, M., Brunner, D., Barò, R., Balzarini, A., Chemel, C., Curci, G., Jiménez-Guerrero, P., Hirtl, M., Honzak, L., Im, U., Pérez, J.L., Pirovano, G., San Jose, R., Schlünzen, K.H., Tsegas, G., Tuccella, P., Werhahn, J., Žabkar, $R$., and Galmarini, S., 2015: Analysis of meteorology-chemistry interactions during air pollution episodes using online coupled models within AQMEII phase-2. Atmos. Environ. 115, 527-540. https://doi.org/10.1016/j.atmosenv.2014.09.020

Kuik, F., Lauer, A., Churkina, G., Denier van der Gon, H.A.C., Fenner, D., Mar, K.A., and Butler, T.M., 2016: Air quality modelling in the Berlin-Brandenburg region using WRF-Chem v3.7.1: sensitivity to resolution of model grid and input data. Geosci. Model Develop. 9, 4339-4363. https://doi.org/10.5194/gmd-9-4339-2016

Leelössy, Á., Mészáros, R., Kovács, A., Lagzi, I., and Kovács, T., 2017: Numerical simulations of atmospheric dispersion of iodine-131 by different models. PLoS ONE, 12, e0172312. https://doi.org/10.1371/journal.pone.0172312

Liao, J., Wang, T., Jiang, Z., Zhuang, B., Xie, M., Yin, C., Wang, X., Zhu, J., Fu, Y., and Zhang, Y., 2015: WRF-Chem modeling of the impacts of urban expansion on regional climate and air pollutants in Yangtze River Delta, China. Atmos. Environ. 106, 204-214. https://doi.org/10.1016/j.atmosenv.2015.01.059

Liu, S., Hua, S., Wang, K., Qiu, P., Liu, H., Wu, B., Shao, P., Liu, X., Wu, Y., Xue, Y., Hao, Y., and Tian, H., 2018: Spatial-temporal variation characteristics of air pollution in Henan of China: Localized emission inventory, WRF/Chem simulations and potential source contribution analysis. Sci. Total Environ. 624, 396-406. https://doi.org/10.1016/j.scitotenv.2017.12.102

Mar, K.A., Ojha, N., Pozzer, A., and Butler, T.M., 2016: Ozone air quality simulations with WRFChem (v3.5.1) over Europe: model evaluation and chemical mechanism comparison. Geosci. Model Develop. 9, 3699-3728. https://doi.org/10.5194/gmd-9-3699-2016

Marécal, V., Peuch, V.-H., Andersson, C., Andersson, S., Arteta, J., Beekmann, M., Benedictow, A., Bergström, R., Bessagnet, B., Cansado, A., Chéroux, F., Colette, A., Coman, A., Curier, R.L., Denier van der Gon, H.A.C., Drouin, A., Elbern, H., Emili, E., Engelen, R.J., Eskes, H.J., Foret, G., Friese, E., Gauss, M., Giannaros, C., Guth, J., Joly, M., Jaumouillé, E., Josse, B., Kadygrov, 
N., Kaiser, J.W., Krajsek, K., Kuenen, J., Kumar, U., Liora, N., Lopez, E., Malherbe, L., Martinez, I., Melas, D., Meleux, F., Menut, L., Moinat, P., Morales, T., Parmentier, J., Piacentini, A., Plu, M., Poupkou, A., Queguiner, S., Robertson, L., Rouïl, L., Schaap, M., Segers, A., Sofiev, M., Tarasson, L., Thomas, M., Timmermans, R., Valdebenito, A., van Velthoven, P., van Versendaal, R., Vira, J., and Ung, A., 2015: A regional air quality forecasting system over Europe: the MACC-II daily ensemble production. Geosci. Model Develop. 8, 27772813. https://doi.org/10.5194/gmd-8-2777-2015

Mészáros, R., Lagzi, I., Gelybó, G., and Leelössy, Á., 2013: Atmospheric Chemistry. Eötvös Loránd University, Budapest.

Mues, A., Lauer, A., Lupascu, A., Rupakheti, M., Kuik, F., and Lawrence, M.G., 2017: Air quality in the Kathmandu Valley: WRF and WRF-Chem simulations of meteorology and black carbon concentrations. Geosci. Model Develop Discuss. 2017, 1-38. https://doi.org/10.5194/gmd-2017-224

Pascal, M., Corso, M., Chanel, O., Declercq, C., Badaloni, C., Cesaroni, G., Henschel, S., Meister, K., Haluza, D., Martin-Olmedo, P., and Medina, S., 2013: Assessing the public health impacts of urban air pollution in 25 European cities: Results of the Aphekom project. Sci. Total Environment, 449, 390-400. https://doi.org/10.1016/j.scitotenv.2013.01.077

Stockwell, W.R., Middleton, P., Chang, J.S., and Xiaoyan, T., 1990: The second generation regional acid deposition model chemical mechanism for regional air quality modeling. J. Geophys. Res. Atmospheres, 95, 16343-16367. doi:10.1029/JD095iD10p16343

WHO (Ed.), 2016: Ambient air pollution: A global assessment of exposure and burden of disease. World Health Organization, Geneva, Switzerland, $131 \mathrm{p}$.

Zaveri, R.A. and Peters, L.K., 1999: A new lumped structure photochemical mechanism for large-scale applications. J. Geophys. Res. Atmospheres, 104, 30387-30415. https://doi.org/10.1029/1999JD900876

Zhang, L., Wang, T., Lv, M., and Zhang, Q., 2015: On the severe haze in Beijing during January 2013: Unraveling the effects of meteorological anomalies with WRF-Chem. Atmos. Environ. 104, 11-21. https://doi.org/10.1016/j.atmosenv.2015.01.001 